\title{
环氧合酶-2/5-脂氧合酶(COX-2/5-LOX)双重抑制剂吲哚-2-酰胺 衍生物的合成及其抗增殖活性
}

\author{
钱诗虎 $a$ 黄元政 $a$ 李家明*,a,b 张艳春 $a, b$ \\ 张 斌 $a$ 金 凡 $a$

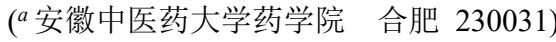 \\ ( $b$ 安徽省中医药科学院药物化学研究所 合肥 230031)
}

\begin{abstract}
摘要 设计并合成了一系列新的吲哚-2-酰胺衍生物作为环氧合酶-2/5-脂氧合酶(COX-2/5-LOX)双重抑制剂, 并评估了 它们的抗增殖活性. 其中, (5-氯-1-(4-氟苄基)- $1 \mathrm{H}$-吲哚-2-基)(4-(4-甲氧基苄基)哌嗪-1-基)甲酮(12h)对人结肠癌细胞 (HCT-116)、人胃癌细胞(SGC-7901)和人非小细胞肺癌细胞(A549)的抑制活性强于塞来昔布; (5-氯-1-(4-甲氧基苄 基)-1 $\mathrm{H}$-吲哚-2-基)(4-(4-甲氧基苄基)哌嗪-1-基)甲酮(7b)对 A549 ( $\mathrm{IC}_{50}=6.47 \mu \mathrm{mol} \cdot \mathrm{L}^{-1}$ )和 $\mathrm{HCT}-116\left(\mathrm{IC}_{50}=13.80 \mu \mathrm{mol} \cdot \mathrm{L}^{-}\right.$ ${ }^{1}$ )细胞表现出显著的抗增殖活性. 化合物 $7 \mathbf{b}$ 作为抗增殖实验中最具潜力的化合物, 显示出良好的 COX-2 $\left(\mathrm{IC}_{50}=85.04\right.$ $\left.\mathrm{nmol} \cdot \mathrm{L}^{-1}\right)$ 和 $5-\mathrm{LOX}\left(\mathrm{IC}_{50}=125.3 \mathrm{nmol} \cdot \mathrm{L}^{-1}\right)$ 抑制活性. 对接分析表明, 吲哚环上的取代基有利于改善化合物与酶的亲和 力. 进一步的研究证实 $7 \mathbf{b}$ 可以剂量依赖性地诱导 A549 细胞调亡.
\end{abstract}

关键词＼cjkstart吲哚; 抗肿瘤; 环氧合酶(COX); 5-脂氧合酶(5-LOX); 对接

\section{Synthesis and Anti-proliferative Activity of Indole-2-amide Derivatives as Cyclooxygenase-2/5-lipoxygenase (COX-2/5-LOX) Dual Inhibitors}

\author{
Qian, Shihu ${ }^{a}$ \\ Huang, Yuanzheng ${ }^{a}$ \\ Li, Jiaming*,a,b \\ Zhang, Yanchun ${ }^{a, b}$ \\ Zhang, Bin ${ }^{a}$ \\ Jin, $\operatorname{Fan}^{a}$ \\ $\left({ }^{a}\right.$ School of Pharmacy, Anhui University of Chinese Medicine, Hefei 230031) \\ $\left({ }^{b}\right.$ Department of Medicinal Chemistry, Anhui Academy of Chinese Medicine, Hefei 230031)
}

\begin{abstract}
A novel series of indole-2-amide-derived cyclooxygenase-2/5-lipoxygenase (COX-2/5-LOX) dual inhibitors were designed and synthesized, and biologically evaluated as anti-proliferative agents. Among them, (5-chloro-1-(4-fluorobenzyl)-1H-indol-2-yl)(4-(4-methoxy-benzyl)piperazin-1-yl)methanone (12h) exhibited stronger inhibitory activity against three tumor strains of HCT-116, SGC-7901 and A549 than celecoxib, and (5-chloro-1-(4-methoxybenzyl)-1H-indol-2-yl)(4(4-methoxybenzyl)piperazin-1-yl)methanone (7b) displayed outstanding anti-proliferative activity against $\mathrm{A} 549\left(\mathrm{IC}_{50}=6.47\right.$ $\left.\mu \mathrm{mol} \cdot \mathrm{L}^{-1}\right)$ and $\mathrm{HCT}-116\left(\mathrm{IC}_{50}=13.80 \mu \mathrm{mol} \cdot \mathrm{L}^{-1}\right)$ cell lines. As the most potent compound in anti-proliferative assay, $7 \mathbf{b}$ demonstrated attractive COX-2 $\left(\mathrm{IC}_{50}=85.04 \mathrm{nmol} \cdot \mathrm{L}^{-1}\right)$ and 5 - $\mathrm{LOX}\left(\mathrm{IC}_{50}=125.3 \mathrm{nmol} \cdot \mathrm{L}^{-1}\right)$ inhibitory activities. As revealed by the docking analysis, the substituents on the indole ring were beneficial for improving the binding affinity to the enzyme. Further investigation confirmed that $\mathbf{7 b}$ could induce the apoptosis of A549 cells in a dose-dependent manner.

Keywords indole; anti-tumor; cyclooxygenase (COX); 5-lipoxygenase (5-LOX); docking
\end{abstract}

\section{Introduction}

Malignant tumors are the leading cause of human death worldwide, and their incidence is still rising. ${ }^{[1]}$ During the past few years, increasing evidence has manifested that chronic inflammation mediates a variety of diseases such as cancer, arthritis, obesity, and diabetes. ${ }^{[2]}$ In the tumor micro- environment, there are many related inflammatory mediators such as cytokines, chemokines and growth factors, and they play an crucial role in tumor growth and metastatic spread. $^{[3]}$ Arachidonic acid (AA) metabolism, cyclooxygenase (COX) and lipoxygenase (LOX) play important roles in related inflammatory cascades. Thus, inhibiting inflammation-related targets that contribute to carcinogen-

* Corresponding author. E-mail: lijiaming2017@sina.com

Received July 31, 2020; revised October 23, 2020; published online December 18, 2020 
esis can offer rational therapeutic strategies for cancer. ${ }^{[4]}$

Non-steroidal anti-inflammatory drugs (NSAIDs), with COX as the therapeutic target, are the first-line drugs for the treatment of inflammation. COX is one of the main metabolic enzymes in the AA pathway, contributing to the production of prostaglandins (PGs) and thromboxanes (TXs). ${ }^{[5]}$ It is well known that COX exists in two isoforms, termed as COX-1 and COX-2. COX-1 belongs to house-keeper enzymes and is related to gastrointestinal homeostasis, and COX-2 is an inducible enzyme commonly expressed in inflammatory tissues, which has been demonstrated to be closely related to the development of lung cancer, colon cancer and gastric cancer. ${ }^{[6]}$ Classical NSAIDs such as acetylsalicylic acid have been investigated in combination with immunotherapeutics, and gratifying results have been observed. However, severe gastrointestinal side effects of classical NSAIDs limit its long-term use in cancer therapy. ${ }^{[7]}$ Furthermore, selective COX-2 inhibitors, as exemplified by celecoxib, have been validated to exhibit anti-cancer activity and be effective in preventing tumor. However, the treatment of chronic diseases by selective COX-2 inhibitors suffers from the dangerous cardiovascular side effects. ${ }^{[8]}$

LOX is the other important metabolic enzyme in the AA pathway and responsible for leukotrienes production. Studies have illustrated that 5-LOX plays an important role in the development of tumors, including colon cancer and gastric cancer. ${ }^{[9]}$ Over-expression of 5-LOX and overproduction of leukotrienes were observed in a variety of the human tumor cells. ${ }^{[10]}$ It is worth noting that the AA pathway has a compensatory mechanism. When COX-2 is over inhibited, the metabolism of AA would switch to the LOX pathway, resulting in an abnormal increase in leukotrienes levels. This may be another potential cause of side effects of COX-2 inhibitors. ${ }^{[11]}$ Therefore, moderate inhibition of both COX-2 and 5-LOX may obtain synergism and more favorable safety in comparison with excessive inhibition of a single target. ${ }^{[12]}$

In the previous study, we have discovered a series of compounds featuring an indole-2-amide scaffold as COX-2/ 5-LOX dual inhibitors. ${ }^{[13]}$ Among them, compound $\mathbf{1 2 h}$ exhibited remarkable inhibitory activity against both COX and 5-LOX (Figure 1). Considering the relationship between COX/5-LOX and cancer, in this research, it was employed as a lead compound for exploring novel anti-proliferative agents. The structure-activity relationship (SAR) study focusing on the substituents of the indole moiety, N-1 benzyl and the benzyl attached to the piperazine led to the discovery of $\mathbf{7 b}$ with promising anti-proliferative activity.

\section{Results and discussion}

\subsection{Chemical synthesis}

The preparation of the key carboxylic acid fragments $\mathbf{5 a} \sim \mathbf{5} \mathbf{k}$ is shown in Scheme 1. Various substituted in dole-2-carboxylic acids were firstly converted into corresponding methyl esters. The resultant products experience

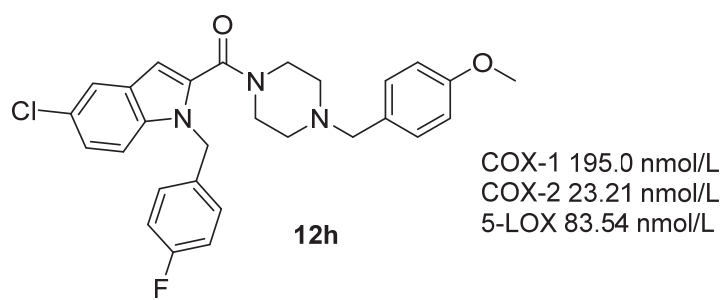

Figure 1 Structure of compound $\mathbf{1 2 h}$
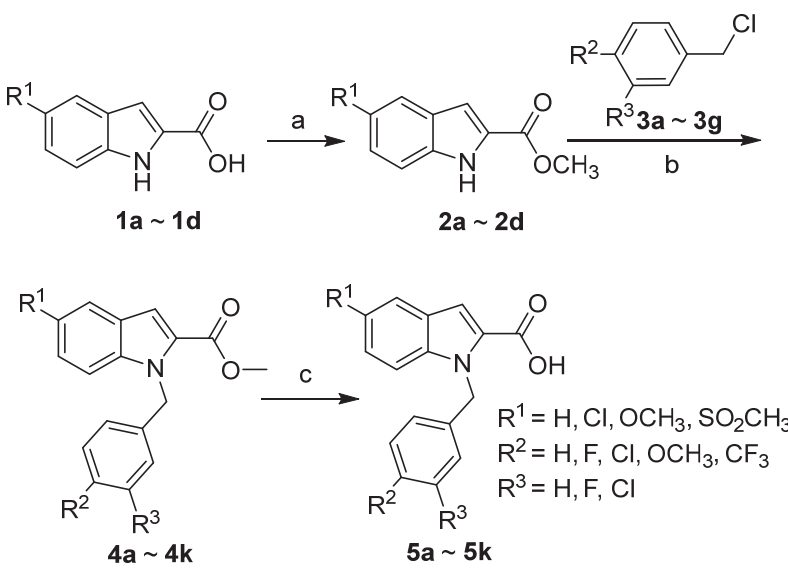

Reagents and conditions: (a) $\mathrm{SOCl}_{2}$, methanol, $75{ }^{\circ} \mathrm{C}$; (b) Appropriate benzyl chloride, $\mathrm{NaH}$, DMF, r.t.; (c) $\mathrm{NaOH}$, alcohol, $75{ }^{\circ} \mathrm{C}$

Scheme 1 Synthetic pathways for compounds $\mathbf{5 a} \sim \mathbf{5 k}$

$\mathrm{N}$-benzylation and subsequent hydrolysis to furnish $\mathbf{5 a} \sim$ 5k. ${ }^{[13-14]}$ Compounds $\mathbf{2 a} \sim \mathbf{2 d}, \mathbf{4 a} \sim \mathbf{4 k}$ and $\mathbf{5 a} \sim \mathbf{5 k}$ were prepared according to Refs. [13-14] and the characterization data were consistent with the literature.

As displayed in Scheme 2, substituted benzyl chlorides $\mathbf{3 a} \sim 3 \mathbf{c}$ were reacted with piperazine to provide $\mathbf{6 a} \sim \mathbf{6} \mathbf{c}^{[15]}$ Then, they were condensed with $\mathbf{5 a} \sim \mathbf{5 k}$ to afford $\mathbf{7 a} \sim \mathbf{7 m}$ as the target compounds. ${ }^{[16]}$ All the target compounds were structurally characterized by ${ }^{1} \mathrm{H}$ NMR, ${ }^{13} \mathrm{C}$ NMR and ESI-MS.

\subsection{In vitro anti-proliferative activity}

All the target compounds, as well as $\mathbf{1 2 h}$, were evaluated for their anti-proliferative activity against three different cancer cell lines by methyl thiazolyl tetrazolium (MTT) assay with celecoxib and 5-fluorouracil (5-FU) as the positive controls (Table 1). The results demonstrated that $\mathbf{1 2 h}$, $\mathbf{7 b}$ and $7 \mathbf{f}$ exhibited attractive anti-proliferative activity. In particular, $12 \mathbf{h}$ displayed superior activity to that of celecoxib against all the three tested cell lines, and $7 \mathbf{b}$ exerted favorable activity against $\mathrm{A} 549\left(\mathrm{IC}_{50}=6.47 \mu \mathrm{mol} \cdot \mathrm{L}^{-}\right.$ $\left.{ }^{1}\right)$ and $\mathrm{HCT}-116\left(\mathrm{IC}_{50}=13.80 \mu \mathrm{mol} \cdot \mathrm{L}^{-1}\right)$ cell lines.

\subsection{In vitro enzymatic inhibition assay}

\subsubsection{In vitro COX-1/COX-2 enzymatic inhibition} assay

The inhibitory activity of compounds $7 \mathbf{a} \sim 7 \mathbf{m}$ against COX-1 and COX-2 was further investigated with celecoxib as the positive control (Table 2). In general, the tested compounds demonstrated moderate to potent inhibitory 

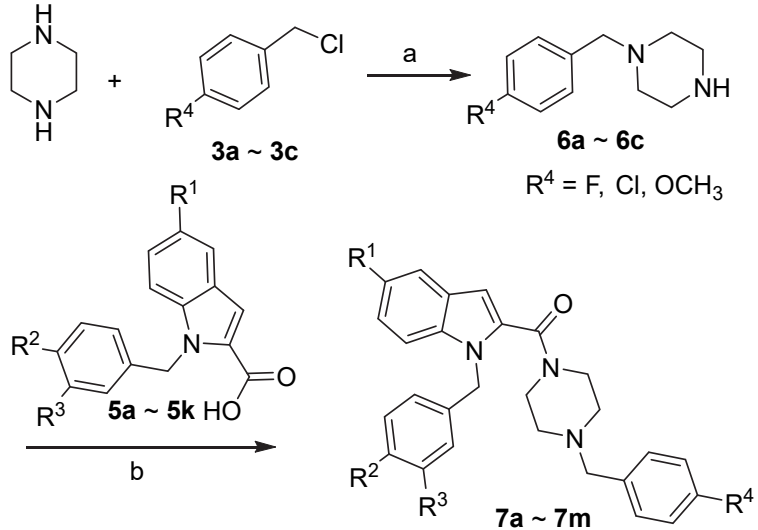

\begin{tabular}{|c|c|c|c|c|c|c|}
\hline Compd. & $\mathrm{R}^{1}$ & $\mathrm{R}^{2}$ & $\mathrm{R}^{3} \quad \mathrm{R}^{4}$ & Compd. & $\mathrm{R}^{1}$ & $\mathrm{R}^{2} \mathrm{R}^{3} \quad \mathrm{R}^{4}$ \\
\hline $7 a$ & $\mathrm{Cl}$ & $\mathrm{Cl}$ & $\mathrm{H} \mathrm{OCH}$ & $7 \mathrm{~h}$ & $\mathrm{OCH}_{3}$ & $\mathrm{Cl} \mathrm{HOCH}$ \\
\hline $7 b$ & $\mathrm{Cl}$ & $\mathrm{OCH}_{3}$ & $\mathrm{H} \mathrm{OCH}$ & $7 i$ & $\mathrm{OCH}_{3}$ & $\mathrm{Cl} \mathrm{H} \quad \mathrm{Cl}$ \\
\hline $7 c$ & $\mathrm{Cl}$ & $\mathrm{CF}_{3}$ & $\mathrm{H} \mathrm{OCH}$ & $7 \mathbf{j}$ & $\mathrm{H}$ & $\mathrm{Cl} \mathrm{H} \quad \mathrm{Cl}$ \\
\hline $7 d$ & $\mathrm{Cl}$ & $\mathrm{H}$ & $\mathrm{F} \quad \mathrm{OCH}_{3}$ & $7 k$ & $\mathrm{H}$ & $\mathrm{F} \mathrm{HOCH}$ \\
\hline $7 e$ & $\mathrm{Cl}$ & $\mathrm{CH}_{3}$ & $\mathrm{HOCH}$ & 71 & $\mathrm{H}$ & $\mathrm{F} \mathrm{H} \quad \mathrm{F}$ \\
\hline $7 f$ & $\mathrm{Cl}$ & $\mathrm{H}$ & $\mathrm{Cl} \mathrm{OCH}_{3}$ & $7 m$ & $\mathrm{SO}_{2} \mathrm{CH}_{3}$ & $\mathrm{~F} \mathrm{HOCH}$ \\
\hline $7 \mathrm{~g}$ & $\mathrm{OCH}_{3}$ & $\mathrm{~F}$ & $\mathrm{H} \mathrm{OCH}$ & & & \\
\hline
\end{tabular}

Reagents and conditions: (a) potassium carbonate, $\mathrm{CH}_{2} \mathrm{Cl}_{2}$, r.t.; (b) EDCI, HOBT, Triethanolamine, DMF, r.t.

Scheme 2 Synthetic pathway for compounds $7 \mathbf{a} \sim 7 \mathbf{m}$

Table 1 Anti-proliferative activities of target compounds, celecoxib, 5-FU and $\mathbf{1 2 h}$ against different cancer cell lines

\begin{tabular}{llll}
\hline \multirow{2}{*}{ Compd. } & \multicolumn{3}{c}{$\mathrm{IC}_{50} a, b /\left(\mu \mathrm{mol} \cdot \mathrm{L}^{-1}\right)$} \\
\cline { 2 - 4 } & \multicolumn{1}{c}{ HCT-116 } & \multicolumn{1}{c}{ SGC-7901 } & \multicolumn{1}{c}{ A549 } \\
\hline Celecoxib & $37.63 \pm 2.14$ & $48.73 \pm 3.29$ & $22.23 \pm 1.89$ \\
5-FU & $20.23 \pm 1.26$ & $40.20 \pm 2.76$ & $44.32 \pm 3.26$ \\
12h & $22.32 \pm 0.30$ & $26.98 \pm 1.67$ & $13.72 \pm 0.61$ \\
7a & $92.26 \pm 6.28$ & $66.62 \pm 4.55$ & $89.02 \pm 5.61$ \\
7b & $13.80 \pm 1.05$ & $90.79 \pm 6.59$ & $6.47 \pm 0.43$ \\
$\mathbf{7 c}$ & $39.93 \pm 2.67$ & $106.80 \pm 7.18$ & $31.94 \pm 2.17$ \\
$\mathbf{7 d}$ & $101.90 \pm 6.97$ & $46.79 \pm 2.62$ & $114.20 \pm 7.86$ \\
$\mathbf{7 e}$ & $83.10 \pm 5.21$ & $36.86 \pm 2.37$ & $53.78 \pm 3.64$ \\
$\mathbf{7 f}$ & $17.63 \pm 1.17$ & $66.33 \pm 4.18$ & $32.35 \pm 2.04$ \\
$\mathbf{7 g}$ & $101.40 \pm 7.62$ & $100.00 \pm 7.93$ & $70.10 \pm 3.78$ \\
$\mathbf{7 h}$ & $169.30 \pm 13.45$ & $85.16 \pm 5.67$ & $207.90 \pm 12.38$ \\
$\mathbf{7 i}$ & $160.80 \pm 11.69$ & $123.50 \pm 10.09$ & $68.14 \pm 3.76$ \\
$\mathbf{7 j}$ & $150.30 \pm \pm 10.15$ & $197.30 \pm 14.66$ & $357.80 \pm 19.98$ \\
$\mathbf{7 k}$ & $39.23 \pm 2.15$ & $100.50 \pm 7.84$ & $35.48 \pm 2.67$ \\
$\mathbf{7 l}$ & $142.70 \pm 11.98$ & $362.80 \pm 20.11$ & $121.00 \pm 8.27$ \\
$\mathbf{7 m}$ & $90.71 \pm 6.55$ & $60.98 \pm 4.16$ & $143.60 \pm 8.91$ \\
\hline
\end{tabular}

${ }^{a} \mathrm{IC}_{50}$ : concentration inhibit $50 \%$ of cell growth. Inhibition rate $(\%)=$ $[\mathrm{OD}$ (value of control group) $-\mathrm{OD}$ (value of experimental group) $] / \mathrm{OD}$ (value of control group) $\times 100 \%, \mathrm{IC}_{50}$ value is calculated and analyzed by Graphpad 5.0 software. ${ }^{b}$ Data are shown as the mean \pm SD of three independent experiments $(n=3)$ run in triplicate

activity against COX-2. Compound $\mathbf{7 b}$, as the most potent COX-2 inhibitor throughout this series, displayed $\mathrm{IC}_{50}$ of 85 $\mathrm{nmol} \cdot \mathrm{L}^{-1}$ and over 10 -fold selectivity over COX-1.

2.3.2 In vitro 5-LOX enzymatic inhibition assay

The target compounds were assayed against 5-LOX for
Table 2 In vitro COX enzymatic inhibition assay of the compounds $7 \mathbf{a} \sim 7 \mathbf{m}$

\begin{tabular}{ccc}
\hline \multirow{2}{*}{ Compd. } & \multicolumn{2}{c}{$\mathrm{IC}_{50}{ }^{a} /\left(\mathrm{nmol}^{\circ} \mathrm{L}^{-1}\right)$} \\
\cline { 2 - 3 } & COX-1 & COX-2 \\
\hline $\mathbf{7 a}$ & $916.4 \pm 134.9$ & $130.9 \pm 6.14$ \\
$\mathbf{7 b}$ & $897.0 \pm 30.18$ & $85.04 \pm 5.71$ \\
$\mathbf{7 c}$ & $678.5 \pm 88.60$ & $614.2 \pm 91.72$ \\
$\mathbf{7 d}$ & $766.2 \pm 188.9$ & $321.5 \pm 89.94$ \\
$\mathbf{7 e}$ & $1334.7 \pm 173.8$ & $365.3 \pm 77.71$ \\
$\mathbf{7 f}$ & $1128.0 \pm 50.89$ & $312.4 \pm 15.77$ \\
$\mathbf{7 g}$ & $1128.5 \pm 184.8$ & $370.5 \pm 46.50$ \\
$\mathbf{7 h}$ & $1920.2 \pm 95.86$ & $337.6 \pm 36.12$ \\
$\mathbf{7 i}$ & $1407.1 \pm 489.2$ & $734.0 \pm 194.7$ \\
$\mathbf{7 j}$ & $1390.5 \pm 317.8$ & $559.3 \pm 61.22$ \\
$\mathbf{7} \mathbf{k}$ & $1550.1 \pm 317.3$ & $335.2 \pm 33.87$ \\
$\mathbf{7 l}$ & $1289.6 \pm 240.8$ & $865.1 \pm 140.3$ \\
$\mathbf{7 m}$ & $2670.3 \pm 285.4$ & $365.8 \pm 108.8$ \\
Celecoxib & $14993 \pm 794.5$ & $11.1 \pm 0.79$ \\
\hline
\end{tabular}

${ }^{a} \mathrm{IC}_{50}$ represents the concentration of the test compound that is required for $50 \%$ inhibition in vitro. Inhibition rate $(\%)=[\mathrm{RFU}(100 \%$ enzyme activity control) - RFU(sample)/[RFU(100\% enzyme activity control) - RFU(blank control) $] \times 100 \%, \mathrm{IC}_{50}$ value is calculated and analyzed by Graphpad 5.0 software.

their inhibitory activity with zileuton as the positive reference (Table 3). Among them, 7c and $\mathbf{7 f}$ exhibited comparable 5-LOX inhibitory activity to that of zileuton with $\mathrm{IC}_{50}$ at two-digit nanomolar level. Besides, $\mathbf{7 b}$ and $7 \mathbf{l}$ displayed acceptable 5-LOX inhibitory activity with $\mathrm{IC}_{50}$ values of 125.3 and $101.0 \mathrm{nmol} \cdot \mathrm{L}^{-1}$, respectively. The attractive COX and 5-LOX dual inhibitory of $\mathbf{7 b}$ and $7 \mathbf{f}$ may account for their acceptable anti-proliferative activity.

Table 3 In vitro 5-LOX enzymatic inhibition assay of the compounds $7 \mathbf{a} \sim 7 \mathrm{~m}$

\begin{tabular}{cc}
\hline Compd. & $\mathrm{IC}_{50}{ }^{a} /\left(\mathrm{nmol}^{\circ} \mathrm{L}^{-1}\right)$ \\
\hline $\mathbf{7 a}$ & $626.9 \pm 45.18$ \\
$\mathbf{7 b}$ & $125.3 \pm 7.04$ \\
$\mathbf{7 c}$ & $65.37 \pm 4.15$ \\
$\mathbf{7 d}$ & $467.6 \pm 30.54$ \\
$\mathbf{7 e}$ & $471.5 \pm 33.27$ \\
$\mathbf{7 f}$ & $33.1 \pm 1.83$ \\
$\mathbf{7 g}$ & $679 \pm 42.63$ \\
$\mathbf{7 h}$ & $226.1 \pm 12.58$ \\
$\mathbf{7 i}$ & $655.3 \pm 39.67$ \\
$\mathbf{7 j}$ & $827 \pm 62.73$ \\
$\mathbf{7} \mathbf{k}$ & $531.4 \pm 29.11$ \\
$\mathbf{7 l}$ & $101 \pm 8.57$ \\
$\mathbf{7 m}$ & $314.3 \pm 23.19$ \\
Zileuton & $39.7 \pm 2.31$ \\
\hline
\end{tabular}

${ }^{a} \mathrm{IC}_{50}$ represents the concentration of the test compound that is required for $50 \%$ inhibition in vitro. Inhibition rate $(\%)=[\mathrm{OD}(100 \%$ enzyme activity control $)-\mathrm{OD}($ sample $)] /[\mathrm{OD}(100 \%$ enzyme activity control $)-\mathrm{OD}$ (blank control) $] \times 100 \%, \mathrm{IC}_{50}$ value is calculated and analyzed by Graphpad 5.0 software.

Also, the structure-activity relationship of these compounds was discussed. When the substituent $\mathrm{R}^{1}$ at the $\mathrm{C}-5$ position of indole is chlorine, compounds show stronger anti-proliferative activity and better COX-2 selectivity. 
When the substituent $\mathrm{R}^{2}$ is a relatively hydrophilic methoxy group, COX-2 enzyme inhibitory activity is improved. When the substituent $\mathrm{R}^{3}$ is chlorine, 5-LOX enzyme inhibitory activity is improved. Some preliminary SAR can be deduced. The chlorine at the C-5 position of indole was beneficial for activity and COX-2 selectivity.

\subsection{Molecular docking study}

Docking study was performed to gain a better understanding of the binding modes of compounds $7 \mathbf{b}, 7 \mathbf{g}, 7 \mathbf{k}$ and $7 \mathbf{m}$ to COX-2 on the basis of the COX-2/SC-588 co-crystal structure (PDB code: 1CX2). ${ }^{[17]} \mathrm{COX}-2$ binding site was present an additional side pocket because of the presence of amino acid residue VAL523. ${ }^{[18]}$ The chlorine atom at the C-5 position of the indole ring of compound $7 \mathbf{b}$ can be inserted into this side pocket of COX-2. At the same time, the chlorine atom formed a hydrophobic interaction with amino acid HIS90 and ALA516. In addition, the methoxy group formed a hydrogen bond with the key amino acid ARG120, which might enhance the binding affinity (Figure $2 \mathrm{~A})$. Similar to $\mathbf{7 b}$, the indole ring of compound $\mathbf{7 k}$ can be also inserted into this side pocket of COX-2, and the methoxy group also forms a hydrogen bond with the amino acid ARG120 (Figure 2B). However, compounds 7g and $7 \mathbf{m}$ failed to be docked into $\mathrm{COX}-2$ active pocket due to the large substituent on the indole ring.

According to the results of the enzymatic assay and the docking experiment, it can be seen that the substituents on the indole ring have a significant effect on the activity, possibly due to the potential of some substituents to interact with COX-2 side pocket. However, too large substituents will prevent the molecule from entering the cavity, thereby leading to the loss of potency.

\subsection{Cell apoptosis assay}

Based on the result of the anti-proliferative and COX-2/ 5-LOX inhibitory activity, A549 cells were double stained by Annexin V/PI and subjected to flow cytometry analysis to determine whether compound $\mathbf{7 b}$ with different concentrations could induce apoptosis. After treated with different concentration of $7 \mathbf{b}\left(0,3.125,6.25,12.5,25 \mu \mathrm{mol} \cdot \mathrm{L}^{-1}\right)$ for $48 \mathrm{~h}$, the apoptosis ratio changes with a flow cytometer in vitro was analyzed. As shown in Figure 3, the apoptosis rate of A549 cells increased with the increase of $7 \mathbf{b}$ concentration, from $4.93 \%$ to $16.47 \%, 21.46 \%, 28.27 \%, 37.31 \%$, respectively. It can be seen that $\mathbf{7 b}$ could induce apoptosis
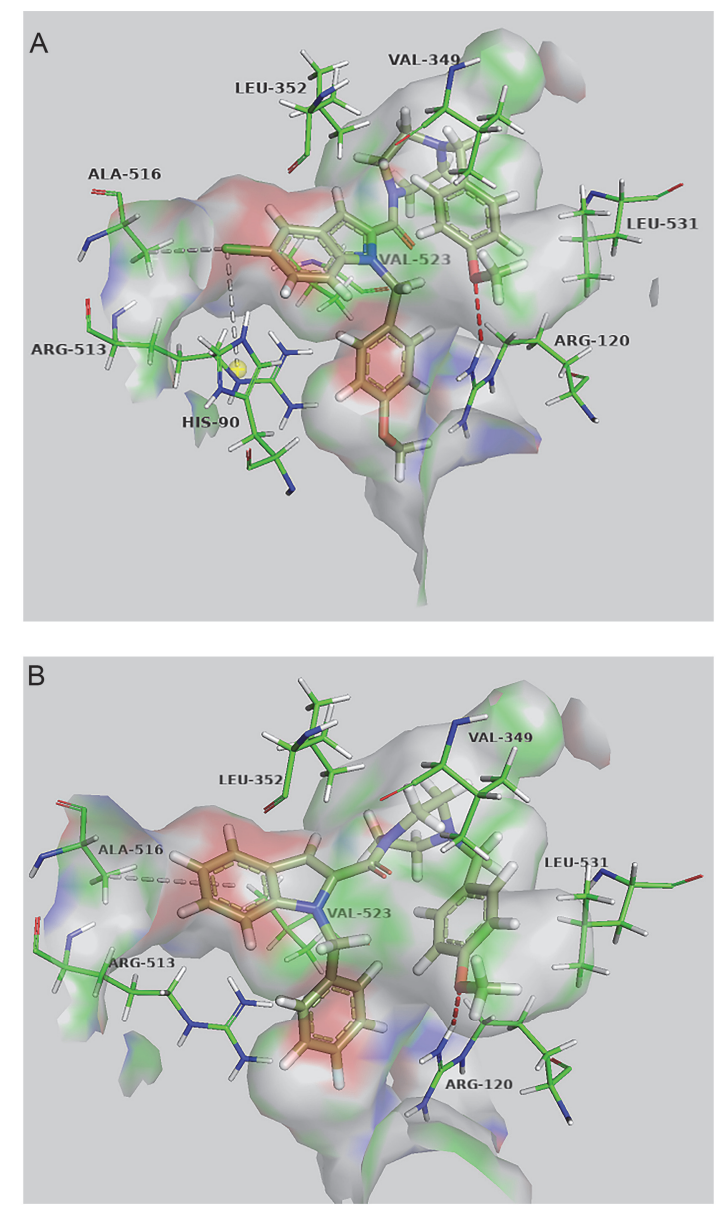

Figure 2 Molecular docking analysis of compounds $7 \mathbf{b}$ and $7 \mathbf{k}$ with COX-2

(A) Docking and binding pattern of compound $7 \mathbf{b}$ (blue) into COX-2 active site (PDB code: 1CX2); (B) docking and binding pattern of compound $7 \mathbf{k}$ (blue) into COX-2 active site. Dashed lines represent hydrogen bonds. The protein surface was represented by green; the amino acid residue was represented by white.

ina dose-dependent manner.

\section{Conclusions}

As a potential cancer treatment strategy, dual inhibitors of COX-2 and 5-LOX have not yet entered the market. In order to further search for COX-2/5-LOX dual inhibitors that increase efficiency of cancer treatment, a series of novel indole-2-amides as dual COX-2 and 5-LOX inhibit-
A

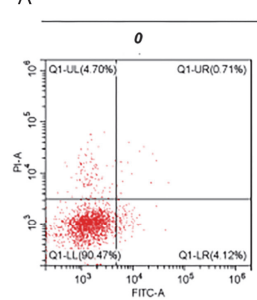

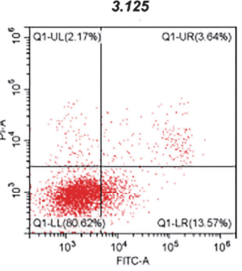

$H 1 /\left(\mu \mathrm{mol} \cdot \mathrm{L}^{-1}\right)$

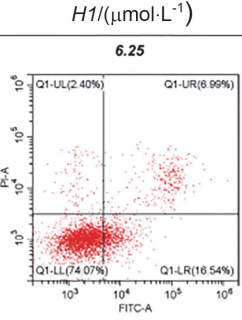

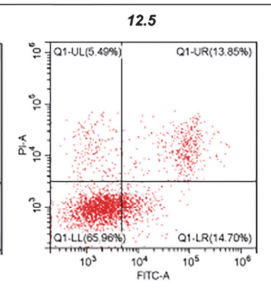

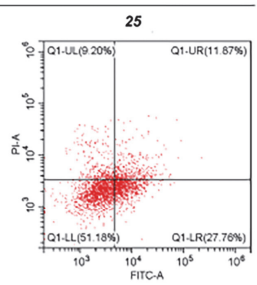

B

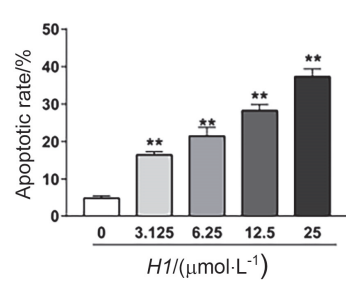

Figure 3 Compound $7 \mathbf{b}$ induced apoptosis in A549 cells

(A) A549 cells were treated with different concentrations of $\mathbf{7 b}$, then apoptosis in A549 cells was assessed by flow cytometer analysis after staining with AnnexinV/PI; (B) Apoptotic ratio. Results were mean \pm SD for 3 individual experiments which, for each condition, were repeated 3 times. ${ }^{* *} p<0.01$, vs. 0 $\mu \mathrm{mol} \cdot \mathrm{L}^{-1}$ group 
ors to treat cancer were designed and synthesized. Compared with celecoxib, COX-2 inhibitor with mild anti-tumor activity, COX-2/5-LOX dual inhibitor is expected to increase the therapeutic effect through the anti-tumor effect of 5-LOX. At the same time, the safety of dual inhibitors is probably higher. Preliminary experiments have confirmed that compounds $\mathbf{1 2 h}, \mathbf{7 b}$, and $\mathbf{7 f}$ have potent anti-proliferative activity against HCT-116, SGC-7901 and A549 cells. Among them, $\mathbf{7 b}$ had the strongest anti-proliferative activity $\left(\mathrm{IC}_{50}=6.47 \mu \mathrm{mol} \cdot \mathrm{L}^{-1}\right.$ for $\mathrm{A} 549$ cells $)$. In subsequent enzyme inhibitory activity experiments, it was found that compounds $\mathbf{7 b}$ and $\mathbf{7 f}$ had weaker inhibitory activity against COX-2 than celecoxib. Then whether the better anti-proliferative activity of compounds $\mathbf{7 b}$ and $\mathbf{7 f}$ are due to their inhibitory activity on 5-LOX are worthy further exploration. The probable binding mode proposed by the docking experiment may be a convincing explanation of the difference activity of compounds $7 \mathbf{b}, 7 \mathbf{g}, 7 \mathbf{k}$ and $\mathbf{7 m}$, in which $7 \mathbf{b}$ could bind eminently to COX-2 through a hydrophobic interaction with side pocket and a hydrogen bond with ARG120. As the change of substituents in the indole ring, the binding capacity of $7 \mathbf{k}$ to COX-2 decreased, while the binding ability of $\mathbf{7 g}$ and $\mathbf{7 m}$ was lost. This result indicates that the substituent in the indole ring is crucial for anti-proliferative activities of synthesized derivatives. In addition, compound $\mathbf{7 b}$ can induce apoptosis in A549 cells in a dose-dependent manner. In summary, compound $\mathbf{7 b}$ as well as the other indole-2-amide derivatives are promising leads for further study as potential anticancer COX-2/5-LOX dual inhibitor.

\section{Experimental section}

\subsection{Chemistry}

Melting points were determined on melting point apparatus (RDCSY-I) and were uncorrected. ${ }^{1} \mathrm{H}$ NMR and ${ }^{13} \mathrm{C}$ NMR spectra were recorded on $400 \mathrm{MHz}$ and $100 \mathrm{MHz}$ instruments (Bruker, Fallanden, Switzerland), respectively, with tetramethylsilane (TMS) as internal standard. MS spectra were measured with a Hewlett-Packard 1100 LC/MSD spectrometer (Agilent, Waldbronn, Germany). The reagents and solvents for reaction were purchased from common commercial suppliers. If necessary, purification processes were carried out prior to their use.

\subsection{General procedure for synthesis of compounds}

To a solution of 5-chloroindole-2-carboxylic acid (5 g, $25.6 \mathrm{mmol}, 1$ eqiuiv.) in $30 \mathrm{~mL}$ of $\mathrm{MeOH}$ was added $\mathrm{SOCl}_{2}$ (3.7 g, $30.8 \mathrm{mmol}, 1.2$ equiv.) dropwise within $30 \mathrm{~min}$ at $0{ }^{\circ} \mathrm{C}$. Subsequently, the reaction mixture was stirred at $35^{\circ} \mathrm{C}$ for $2 \mathrm{~h}$. Then, the solvent was evaporated under reduced pressure, and the residue was purified by column chromatography using petroleum/ethylacetate, giving intermediate 2a as a yellow solid with yield of 93\%. ${ }^{[13-14]}$ Intermediates $\mathbf{2 b} \sim \mathbf{2 d}$ were synthesized according to the synthetic procedure given above. The characterization data were consistent with Refs. [13, 14].

To a stirred suspension of $\mathrm{NaH}(60 \%$ dispersion inmin- eral oil; $0.7 \mathrm{~g}, 17.3 \mathrm{mmol}, 1.2$ equiv.) in $N, N$-dimethylformamide (DMF) $(10 \mathrm{~mL})$ was added dropwise solution of 2a (3 g, 14.4 mmol, 1 equiv.) in $\operatorname{DMF}(30 \mathrm{~mL})$ at $0{ }^{\circ} \mathrm{C}$ and the mixture was stirred at room temperature for $30 \mathrm{~min}$. To the mixture was added dropwise 4-chlorobenzyl chloride (2.32 g, $14.4 \mathrm{mmol}, 1$ equiv.), and the resulting mixture was stirred at room temperature for $30 \mathrm{~min}$. The reaction was quenched with water and acidified with acetic acid. The formed precipitate was filtered, washed with water and dried under vacuum to obtain intermediate $4 \mathbf{a}$ as a gray solid. ${ }^{[13-14]}$ Intermediates $\mathbf{4 b} \sim \mathbf{4 k}$ were synthesized according to the synthetic procedure given above. The characterization data were consistent with Refs. [13, 14].

To a solution of $4 \mathbf{a}(2.6 \mathrm{~g}, 7.8 \mathrm{mmol}, 1$ equiv.) in ethanol $(30 \mathrm{~mL}), 10 \% \mathrm{NaOH}$ solution $(15 \mathrm{~mL})$ was added with stirring for $15 \mathrm{~min}$ at $75{ }^{\circ} \mathrm{C}$. After removal of ethanol under reduced pressure, the residue was then taken into water and acidified with concentrated hydrochloric acid. The formed precipitate was filtered, washed with water and dried under vacuum to give intermediate $\mathbf{5 a}$ as white solid with yield of $85 \%{ }^{[13-14]}$ Intermediates $\mathbf{5 b} \sim \mathbf{5 k}$ were synthesized according to the synthetic procedure given above. The characterization data were consistent with Refs. [13, 14].

Anhydrous piperazine (2.59 g, $30.0 \mathrm{mmol}, 6$ equiv.) was dissolved in dichloromethane $(15 \mathrm{~mL})$. 4-Methoxybenzyl chloride $(0.78 \mathrm{~g}, 5.0 \mathrm{mmol}, 1$ equiv.) was added dropwise to the solution at room temperature. The reaction mixture was stirred for about $4 \mathrm{~h}$. Then, the mixture was washed with saturated $\mathrm{K}_{2} \mathrm{CO}_{3}$ solution $(30 \mathrm{~mL} \times 3)$ and water $(30 \mathrm{~mL} \times$ $3)$. The organic layer was dried over anhydrous $\mathrm{Na}_{2} \mathrm{SO}_{4}$. The filtrate was evaporated under reduced pressure to obtain desired intermediate $6 \mathbf{a}$ with $80 \%$ yield. ${ }^{[15]}$ Intermediates $\mathbf{6 b}$ and $\mathbf{6 c}$ were synthesized according to the synthetic procedure given above. The characterization data were consistent with Ref. [15].

To a stirred solution of 5a ( $0.53 \mathrm{~g}, 1.65 \mathrm{mmol}, 1$ equiv.) in DMF (25 mL), 1-hydroxybenzotriazole (HOBT) $(0.445$ g, 3.3 mmol, 2 equiv.) and ethyl-3-(3-dimethylaminopropyl)carbodiimide hydrochloride (EDCI) (0.79 g, 4.12 mmol, 2.5 equiv.) were added at $25{ }^{\circ} \mathrm{C}$. After $15 \mathrm{~min}, 7 \mathbf{a}$ (0.34 g, 1.65 mmol, 1 equiv.) dissolved in DMF (10 mL) was added. The reaction mixture was continued to keep at $25{ }^{\circ} \mathrm{C}$ with stirring for $4 \mathrm{~h}$. A saturated solution of citric acid was slowly added with stirring for an additional $30 \mathrm{~min}$ followed by addition of $\mathrm{H}_{2} \mathrm{O}$ and EtOAc. The organic layer was washed with brine, dried over anhydrous $\mathrm{Na}_{2} \mathrm{SO}_{4}$ and evaporated under reduced pressure. The residue was purified by flash column chromatography (petroleum/ethylacetate) to obtain compound $7 \mathbf{a}$ with $41.4 \%$ yield. Compounds $\mathbf{7 b} \sim \mathbf{7} \mathbf{m}$ were synthesized according to the synthetic procedure given above.

(5-Chloro-1-(4-chlorobenzyl)-1H-indol-2-yl)(4-(4-methoxybenzyl)piperazin-1-yl)methanone (7a): White solid, yield $41.4 \%$. m.p. 57.9 59.1 ${ }^{\circ} \mathrm{C}$; ${ }^{1} \mathrm{H}$ NMR $(400 \mathrm{MHz}$, DMSO- $\left.d_{6}\right) \delta: 7.71 \sim 7.64(\mathrm{~m}, 2 \mathrm{H}, \operatorname{ArH}), 7.36(\mathrm{~d}, J=8.3 \mathrm{~Hz}$, $2 \mathrm{H}, \mathrm{ArH}), 7.25(\mathrm{~d}, J=7.3 \mathrm{~Hz}, 1 \mathrm{H}, \mathrm{ArH}), 7.18(\mathrm{~d}, J=8.3 \mathrm{~Hz}$, 2H, ArH), 7.06 (d, $J=8.3 \mathrm{~Hz}, 2 \mathrm{H}, \mathrm{ArH}), 6.88(\mathrm{~d}, J=8.3 \mathrm{~Hz}$, 
$2 \mathrm{H}, \mathrm{ArH}), 6.69(\mathrm{~s}, 1 \mathrm{H}, \mathrm{NC}=\mathrm{CH}), 5.50\left(\mathrm{~s}, 2 \mathrm{H}, \mathrm{ArCH}_{2}\right), 3.73$ $\left(\mathrm{s}, 3 \mathrm{H}, \mathrm{ArOCH}_{3}\right), 3.65 \sim 3.45(\mathrm{~m}, 6 \mathrm{H}$, piperazine- $\mathrm{H}$, $\left.\mathrm{ArCH}_{2}\right), 2.39 \sim 1.83$ (m, 4H, piperazine-H); ${ }^{13} \mathrm{C}$ NMR (101 $\left.\mathrm{MHz}, \mathrm{DMSO}-d_{6}\right) \delta: 161.82,158.84,137.49,136.05$, $133.39,132.55,130.55,129.95,129.42,129.11,127.58$, $125.30,123.69,120.99$, 114.08, 112.74, 103.82, 61.69, 55.46, 52.53, 46.79; HRMS calcd for $\mathrm{C}_{28} \mathrm{H}_{28} \mathrm{Cl}_{2} \mathrm{~N}_{3} \mathrm{O}_{2}[\mathrm{M}+$ $\mathrm{H}]^{+}$508.1559, found 508.1554.

(5-Chloro-1-(4-methoxybenzyl)-1 $H$-indol-2-yl)(4-(4methoxybenzyl)piperazin-1-yl)methanone (7b): White solid, yield $42.6 \%$. m.p. $130.1 \sim 131.8{ }^{\circ} \mathrm{C} ;{ }^{1} \mathrm{H}$ NMR (400 $\left.\mathrm{MHz}, \mathrm{DMSO}-d_{6}\right) \delta: 7.71 \sim 7.66(\mathrm{~m}, 2 \mathrm{H}, \mathrm{ArH}), 7.24(\mathrm{~d}, J=$ $8.8 \mathrm{~Hz}, 1 \mathrm{H}, \mathrm{ArH}), 7.18$ (d, $J=8.1 \mathrm{~Hz}, 2 \mathrm{H}, \mathrm{ArH}), 7.01$ (d, $J=8.2 \mathrm{~Hz}, 2 \mathrm{H}, \mathrm{ArH}), 6.92 \sim 6.83(\mathrm{~m}, 4 \mathrm{H}, \mathrm{ArH}), 6.65(\mathrm{~s}$, $1 \mathrm{H}, \mathrm{NC}=\mathrm{CH}), 5.42\left(\mathrm{~s}, 2 \mathrm{H}, \mathrm{ArCH}_{2}\right), 3.78 \sim 3.70(\mathrm{~m}, 6 \mathrm{H}$, $\left.\mathrm{ArOCH}_{3}\right), 3.65 \sim 3.51(\mathrm{~m}, 4 \mathrm{H}$, piperazine- $\mathrm{H}), 3.32(\mathrm{~s}, 2 \mathrm{H}$, $\left.\mathrm{ArCH}_{2}\right), 2.40 \sim 1.89$ (m, 4H, piperazine-H); ${ }^{13} \mathrm{C}$ NMR $(101$ $\mathrm{MHz}$, DMSO- $\left.d_{6}\right) \delta: 162.04,159.11,158.83,135.98$, $133.55,130.53,130.38,129.99,128.95,127.59,125.11$, $123.47,120.87,114.49,114.07,112.81,103.46,61.68$, $55.56,55.46,52.53,46.83$; HRMS calcd for $\mathrm{C}_{29} \mathrm{H}_{31} \mathrm{ClN}_{3} \mathrm{O}_{3}$ $[\mathrm{M}+\mathrm{H}]^{+}$504.2054, found 504.2052.

(5-Chloro-1-(4-(trifluoromethyl)benzyl)-1H-indol-2-yl)(4-(4-methoxybenzyl)piperazin-1-yl)methanone (7c): White solid, yield 40.4\%. m.p. $131.3 \sim 133.2{ }^{\circ} \mathrm{C}$; ${ }^{1} \mathrm{H}$ NMR $\left(400 \mathrm{MHz}, \mathrm{DMSO}-d_{6}\right) \delta: 7.72 \sim 7.65$ (m, 4H, ArH), 7.26 $(\mathrm{dd}, J=8.8,2.1 \mathrm{~Hz}, 1 \mathrm{H}, \mathrm{ArH}), 7.22(\mathrm{~d}, J=8.1 \mathrm{~Hz}, 2 \mathrm{H}$, $\operatorname{ArH}), 7.16(\mathrm{~d}, J=8.5 \mathrm{~Hz}, 2 \mathrm{H}, \mathrm{ArH}), 6.87$ (d, $J=8.5 \mathrm{~Hz}, 2 \mathrm{H}$, $\mathrm{ArH}), 6.73(\mathrm{~s}, 1 \mathrm{H}, \mathrm{NC}=\mathrm{CH}), 5.62\left(\mathrm{~s}, 2 \mathrm{H}, \mathrm{ArCH}_{2}\right), 3.73(\mathrm{~s}$, $\left.3 \mathrm{H}, \mathrm{ArOCH}_{3}\right), 3.60 \sim 3.44(\mathrm{~m}, 4 \mathrm{H}$, piperazine-H), $3.28(\mathrm{~s}$, $\left.2 \mathrm{H}, \mathrm{ArCH}_{2}\right), 2.25 \sim 1.92\left(\mathrm{~m}, 4 \mathrm{H}\right.$, piperazine-H); ${ }^{13} \mathrm{C} \mathrm{NMR}$ $\left(101 \mathrm{MHz}, \mathrm{DMSO}-d_{6}\right) \delta: 161.71,158.83,143.30,136.13$, $133.38,130.43,129.99,128.56\left(J_{\mathrm{C}-\mathrm{F}}=31.12 \mathrm{~Hz}\right), 128.11$, $126.02\left(J_{\mathrm{C}-\mathrm{F}}=3.02 \mathrm{~Hz}\right), 125.71\left(J_{\mathrm{C}-\mathrm{F}}=380.18 \mathrm{~Hz}\right)$, $125.41,121.06,114.07,112.72,104.01,61.59,55.45$, 52.66, 47.09; HRMS calcd for $\mathrm{C}_{29} \mathrm{H}_{28} \mathrm{ClF}_{3} \mathrm{~N}_{3} \mathrm{O}_{2}[\mathrm{M}+\mathrm{H}]^{+}$ 548.1822 , found 542.1811 .

(5-Chloro-1-(4-fluorobenzyl)-1H-indol-2-yl)(4-(4-methoxybenzyl)piperazin-1-yl)methanone (7d): White solid, yield $41.3 \%$. m.p. $121.6 \sim 123.8{ }^{\circ} \mathrm{C}$; ${ }^{1} \mathrm{H}$ NMR $(400 \mathrm{MHz}$, DMSO- $\left.d_{6}\right) \delta: 7.70(\mathrm{~d}, J=2.1 \mathrm{~Hz}, 1 \mathrm{H}, \mathrm{ArH}), 7.66(\mathrm{~d}, J=12$ $\mathrm{Hz}, 1 \mathrm{H}, \mathrm{ArH}), 7.32$ (td, $J=8.0,6.0 \mathrm{~Hz}, 1 \mathrm{H}, \mathrm{ArH}), 7.25$ (dd, $J=8.8,2.1 \mathrm{~Hz}, 1 \mathrm{H}, \mathrm{ArH}), 7.19 \sim 7.17$ (m, 2H, ArH), 7.09 $(\mathrm{m}, 1 \mathrm{H}, \mathrm{ArH}), 6.90 \sim 6.86(\mathrm{~m}, 4 \mathrm{H}, \mathrm{ArH}), 6.71(\mathrm{~s}, 1 \mathrm{H}, \mathrm{NC}=$ $\mathrm{CH}), 5.53\left(\mathrm{~s}, 2 \mathrm{H}, \mathrm{ArCH}_{2}\right), 3.74\left(\mathrm{~s}, 3 \mathrm{H}, \mathrm{ArOCH}_{3}\right), 3.61 \sim$ $3.41\left(\mathrm{~m}, 6 \mathrm{H}\right.$, piperazine- $\left.\mathrm{H}, \mathrm{ArCH}_{2}\right), 2.40 \sim 1.93(\mathrm{~m}, 4 \mathrm{H}$, piperazine-H); ${ }^{13} \mathrm{C}$ NMR (101 MHz, DMSO- $\left.d_{6}\right) \delta: 162.67$ $\left(J_{\mathrm{C}-\mathrm{F}}=245.43 \mathrm{~Hz}\right), 161.84,158.84,141.29\left(J_{\mathrm{C}-\mathrm{F}}=7.07\right.$ $\mathrm{Hz}), 136.00,133.41,131.13\left(J_{\mathrm{C}-\mathrm{F}}=9.09 \mathrm{~Hz}\right), 130.57$, $129.89,127.62,125.36,123.74,123.47,123.45,121.01$, $114.90,114.69,114.31\left(J_{\mathrm{C}-\mathrm{F}}=22.22 \mathrm{~Hz}\right), 114.07,112.78$, 103.88, 61.64, 55.46, 52.55, 46.96; HRMS calcd for $\mathrm{C}_{28} \mathrm{H}_{28} \mathrm{ClFN}_{3} \mathrm{O}_{2}[\mathrm{M}+\mathrm{H}]^{+}$492.1854, found 492.1843 .

(5-Chloro-1-(4-methylbenzyl)-1H-indol-2-yl)(4-(4-methoxybenzyl)piperazin-1-yl)methanone (7e): White solid, yield 45.7\% . m.p. 126.3 128.0 ${ }^{\circ} \mathrm{C}$; ${ }^{1} \mathrm{H}$ NMR (400 MHz, DMSO- $\left.d_{6}\right) \delta: 7.69 \sim 7.65(\mathrm{~m}, 2 \mathrm{H}, \mathrm{ArH}), 7.24(\mathrm{dd}, J=8.8$,
$1.8 \mathrm{~Hz}, 1 \mathrm{H}, \mathrm{ArH}), 7.18$ (d, J=8.5 Hz, 2H, ArH), 7.08 (d, $J=7.9 \mathrm{~Hz}, 2 \mathrm{H}, \mathrm{ArH}), 6.95(\mathrm{~d}, J=7.9 \mathrm{~Hz}, 2 \mathrm{H}, \mathrm{ArH}), 6.88(\mathrm{~d}$, $J=8.5 \mathrm{~Hz}, 2 \mathrm{H}, \mathrm{ArH}), 6.66(\mathrm{~s}, 1 \mathrm{H}, \mathrm{NC}=\mathrm{CH}), 5.45(\mathrm{~s}, 2 \mathrm{H}$, $\left.\mathrm{ArCH}_{2}\right), 3.74\left(\mathrm{~s}, 3 \mathrm{H}, \mathrm{ArOCH}_{3}\right), 3.65 \sim 3.40(\mathrm{~d}, 4 \mathrm{H}$, piperazine-H), 3.32 (s, 2H, $\left.\mathrm{ArCH}_{2}\right), 2.30 \sim 1.94$ (m, 7H, piperazine-H, $\left.\mathrm{ArCH}_{3}\right) ;{ }^{13} \mathrm{C}$ NMR (101 MHz, DMSO-d 6$) \delta$ : $161.97,158.83,137.09,136.03,135.43,133.56,130.53$, $129.95,129.63,127.57,127.53,125.13,123.50,120.88$, 114.07, 112.81, 103.52, 61.66, 55.46, 52.52, 47.13, 21.13; HRMS calcd for $\mathrm{C}_{29} \mathrm{H}_{31} \mathrm{ClN}_{3} \mathrm{O}_{2}[\mathrm{M}+\mathrm{H}]^{+} 488.2105$, found 488.2093.

(5-Chloro-1-(3-chlorobenzyl)-1H-indol-2-yl)(4-(4-methoxybenzyl)piperazin-1-yl)methanone (7f): White solid, yield 44\%. m.p. 141.3 142.5 ${ }^{\circ} \mathrm{C}$; ${ }^{1} \mathrm{H}$ NMR (400 MHz, DMSO-d $d_{6} \delta: 7.72(\mathrm{~s}, 1 \mathrm{H}, \mathrm{ArH}), 7.57$ (d, $J=8.8 \mathrm{~Hz}, 1 \mathrm{H}$, ArH), 7.48 (d, $J=7.9 \mathrm{~Hz}, 1 \mathrm{H}, \mathrm{ArH}), 7.32 \sim 7.23(\mathrm{~m}, 2 \mathrm{H}$, ArH), 7.18 (d, $J=8.3 \mathrm{~Hz}, 3 \mathrm{H}, \mathrm{ArH}), 6.88(\mathrm{~d}, J=8.4 \mathrm{~Hz}, 2 \mathrm{H}$, $\mathrm{ArH}), 6.74(\mathrm{~s}, 1 \mathrm{H}, \mathrm{NC}=\mathrm{CH}), 6.51(\mathrm{~d}, J=7.6 \mathrm{~Hz}, 1 \mathrm{H}, \mathrm{ArH})$, $5.61\left(\mathrm{~s}, 2 \mathrm{H}, \mathrm{ArCH}_{2}\right), 3.74\left(\mathrm{~s}, 3 \mathrm{H}, \mathrm{ArOCH}_{3}\right), 3.60 \sim 3.40(\mathrm{~m}$, $6 \mathrm{H}$, piperazine- $\left.\mathrm{H}, \mathrm{ArCH}_{2}\right), 2.30 \sim 1.93(\mathrm{~m}, 4 \mathrm{H}$, piperazine-H); ${ }^{13} \mathrm{C}$ NMR (101 MHz, DMSO- $\left.d_{6}\right) \delta: 161.67,158.84$, $136.30,135.61,133.68,132.10,130.60,129.89,129.59$, $128.66,127.91,127.56,125.37,123.78,121.06,114.06$, 112.78, 103.91, 61.60, 55.48, 52.59, 45.49; HRMS calcd for $\mathrm{C}_{28} \mathrm{H}_{28} \mathrm{Cl}_{2} \mathrm{~N}_{3} \mathrm{O}_{2}[\mathrm{M}+\mathrm{H}]^{+}$508.1559, found 508.1557.

(1-(4-Fluorobenzyl)-5-methoxy-1H-indol-2-yl)(4-(4-methoxybenzyl)piperazin-1-yl)methanone (7g): White solid, yield 45.5\%. m.p. 92.2 94.5 ${ }^{\circ} \mathrm{C}$; ${ }^{1} \mathrm{H}$ NMR (400 MHz, DMSO- $\left.d_{6}\right) \delta: 7.50(\mathrm{~d}, J=8.8 \mathrm{~Hz}, 1 \mathrm{H}, \mathrm{ArH}), 7.18(\mathrm{~d}, J=$ $7.9 \mathrm{~Hz}, 2 \mathrm{H}, \mathrm{ArH}), 7.15 \sim 7.04$ (m, 5H, ArH), 6.87 (d, J= $7.8 \mathrm{~Hz}, 3 \mathrm{H}, \mathrm{ArH}), 6.59(\mathrm{~s}, 1 \mathrm{H}, \mathrm{NC}=\mathrm{CH}), 5.44(\mathrm{~s}, 2 \mathrm{H}$, $\mathrm{NCH}_{2} \mathrm{Ar}$ ), 3.77 (s, 3H, $\left.\mathrm{ArOCH}_{3}\right), 3.74$ (s, 3H, $\mathrm{ArOCH}_{3}$ ), $3.61 \sim 3.43\left(\mathrm{~m}, 6 \mathrm{H}\right.$, piperazine- $\left.\mathrm{H}, \mathrm{ArCH}_{2}\right), 2.40 \sim 1.89(\mathrm{~m}$, $4 \mathrm{H}$, piperazine-H); ${ }^{13} \mathrm{C}$ NMR $\left(101 \mathrm{MHz}, \mathrm{DMSO}-d_{6}\right) \delta$ : $162.44,161.86\left(J_{\mathrm{C}-\mathrm{F}}=244.42 \mathrm{~Hz}\right), 158.84,154.62,135.13$ $\left(J_{\mathrm{C}-\mathrm{F}}=2.02 \mathrm{~Hz}\right), 132.77,132.22,130.57,129.94,129.46$ $\left(J_{\mathrm{C}-\mathrm{F}}=8.08 \mathrm{~Hz}\right), 126.90,115.78\left(J_{\mathrm{C}-\mathrm{F}}=21.21 \mathrm{~Hz}\right), 114.28$, $114.06,111.92,103.99,102.89,61.69,55.79,55.45,52.66$, 46.56; HRMS calcd for $\mathrm{C}_{29} \mathrm{H}_{31} \mathrm{FN}_{3} \mathrm{O}_{3}[\mathrm{M}+\mathrm{H}]^{+}$488.2349, found 488.2342 .

(1-(4-Chlorobenzyl)-5-methoxy-1H-indol-2-yl)(4-(4methoxybenzyl)piperazin-1-yl)methanone (7h): White solid, yield 42.3\%. m.p. 47.4 48.8 ${ }^{\circ} \mathrm{C}$; ${ }^{1} \mathrm{H}$ NMR $(400$ MHz, DMSO- $\left.d_{6}\right) \delta: 7.50(\mathrm{~d}, J=9.0 \mathrm{~Hz}, 1 \mathrm{H}, \mathrm{ArH}), 7.35$ (d, $J=8.3 \mathrm{~Hz}, 2 \mathrm{H}, \operatorname{ArH}), 7.19$ (d, $J=8.4 \mathrm{~Hz}, 2 \mathrm{H}, \operatorname{ArH}), 7.11$ (d, $J=2.0 \mathrm{~Hz}, 1 \mathrm{H}, \mathrm{ArH}), 7.05(\mathrm{~d}, J=8.3 \mathrm{~Hz}, 2 \mathrm{H}, \operatorname{ArH}), 6.88(\mathrm{~d}$, $J=8.2 \mathrm{~Hz}, 3 \mathrm{H}, \mathrm{ArH}), 6.61(\mathrm{~s}, 1 \mathrm{H}, \mathrm{NC}=\mathrm{CH}), 5.46(\mathrm{~s}, 2 \mathrm{H}$, $\left.\mathrm{ArCH}_{2}\right), 3.75\left(\mathrm{~d}, J=12.0 \mathrm{~Hz}, 6 \mathrm{H}, \mathrm{ArOCH}_{3}\right), 3.60 \sim 3.43(\mathrm{~m}$, $6 \mathrm{H}$, piperazine- $\left.\mathrm{H}, \mathrm{ArCH}_{2}\right), 2.26 \sim 1.97(\mathrm{~m}, 4 \mathrm{H}$, piperazine-H); ${ }^{13} \mathrm{C}$ NMR (101 MHz, DMSO- $\left.d_{6}\right) \delta: 162.33,158.84$, $154.64,137.98,132.84,132.37,132.18,130.55,129.99$, $129.32,129.01,126.85,114.33,114.07,111.87,104.08$, 102.91, 61.72, 55.80, 55.46, 52.67, 46.64; HRMS calcd for $\mathrm{C}_{29} \mathrm{H}_{31} \mathrm{ClN}_{3} \mathrm{O}_{3}[\mathrm{M}+\mathrm{H}]^{+}$504.2054, found 504.2045.

(1-(4-chlorobenzyl)-5-methoxy-1브-indol-2-yl)(4-(4-chlorobenzyl)piperazin-1-yl)methanone (7i): White solid, yield 41.6\%. m.p. 103.3 105.5 ${ }^{\circ} \mathrm{C}$; ${ }^{1} \mathrm{H}$ NMR (400 MHz, 
DMSO- $\left.d_{6}\right) \delta: 7.50(\mathrm{~d}, J=8.0 \mathrm{~Hz}, 1 \mathrm{H}, \mathrm{ArH}), 7.41 \sim 7.29(\mathrm{~m}$, $6 \mathrm{H}, \mathrm{ArH}), 7.11(\mathrm{~d}, J=2.2 \mathrm{~Hz}, 1 \mathrm{H}, \mathrm{ArH}), 7.05(\mathrm{~d}, J=8.0 \mathrm{~Hz}$, $2 \mathrm{H}, \mathrm{ArH}), 6.88(\mathrm{dd}, J=9.0,2.3 \mathrm{~Hz}, 1 \mathrm{H}, \mathrm{ArH}), 6.62(\mathrm{~s}, 1 \mathrm{H}$, $\mathrm{NC}=\mathrm{CH}), 5.46\left(\mathrm{~s}, 2 \mathrm{H}, \mathrm{ArCH}_{2}\right), 3.77\left(\mathrm{~s}, 3 \mathrm{H}, \mathrm{ArOCH}_{3}\right)$, $3.62 \sim 3.46\left(\mathrm{~m}, 4 \mathrm{H}\right.$, piperazine-H), $3.40\left(\mathrm{~s}, 2 \mathrm{H}, \mathrm{ArCH}_{2}\right)$, $2.34 \sim 1.90$ (m, 4H, piperazine-H); ${ }^{13} \mathrm{C}$ NMR $(101 \mathrm{MHz}$, DMSO- $\left.d_{6}\right) \delta: 162.35,154.65,137.98,137.32,132.84$, $132.37,132.13,132.06,131.06,129.32,129.01,128.68$, $126.86,114.35,111.88,104.12,102.91,61.35,55.80$, 52.70, 46.66; HRMS calcd for $\mathrm{C}_{28} \mathrm{H}_{28} \mathrm{Cl}_{2} \mathrm{~N}_{3} \mathrm{O}_{2}[\mathrm{M}+\mathrm{H}]^{+}$ 508.1559 , found 504.1545 .

(1-(4-Chlorobenzyl)-1H-indol-2-yl)(4-(4-chlorobenzyl)piperazin-1-yl)methanone (7j): White solid, yield $44.8 \%$. m.p. $119.1 \sim 120.4{ }^{\circ} \mathrm{C} ;{ }^{1} \mathrm{H}$ NMR $\left(400 \mathrm{MHz}, \mathrm{DMSO}-d_{6}\right) \delta$ : $7.61(\mathrm{t}, J=7.7 \mathrm{~Hz}, 2 \mathrm{H}, \mathrm{ArH}), 7.42 \sim 7.29$ (m, 6H, ArH), $7.24(\mathrm{t}, J=8.0 \mathrm{~Hz}, 1 \mathrm{H}, \mathrm{ArH}), 7.13 \sim 7.04(\mathrm{~m}, 3 \mathrm{H}, \mathrm{ArH})$, $6.70(\mathrm{~s}, 1 \mathrm{H}, \mathrm{NC}=\mathrm{CH}), 5.50\left(\mathrm{~s}, 2 \mathrm{H}, \mathrm{ArCH}_{2}\right), 3.61 \sim 3.46(\mathrm{~m}$, $4 \mathrm{H}$, piperazine-H), $3.39\left(\mathrm{~s}, 2 \mathrm{H}, \mathrm{ArCH}_{2}\right), 2.36 \sim 1.89(\mathrm{~m}, 4 \mathrm{H}$, piperazine-H); ${ }^{13} \mathrm{C}$ NMR (101 MHz, DMSO- $\left.d_{6}\right) \delta: 162.33$, $137.86,137.57,137.33,132.41,132.06,131.79,131.06$, $129.41,129.04,128.68,126.47,123.74,121.92,120.76$, $111.00,104.40,61.35,52.72,46.55$; HRMS calcd for $\mathrm{C}_{27} \mathrm{H}_{26} \mathrm{Cl}_{2} \mathrm{~N}_{3} \mathrm{O}[\mathrm{M}+\mathrm{H}]^{+}$478.1453, found 478.1440.

(1-(4-Fluorobenzyl)-1H-indol-2-yl)(4-(4-methoxybenzyl)piperazin-1-yl)methanone (7k): White solid, yield 45.4\%. m.p. 92.4 94.0 ${ }^{\circ} \mathrm{C}$; ${ }^{1} \mathrm{H}$ NMR (400 MHz, DMSO$\left.d_{6}\right) \delta: 7.71 \sim 7.65(\mathrm{~m}, 2 \mathrm{H}, \operatorname{ArH}), 7.25(\mathrm{dd}, J=8.8,1.9 \mathrm{~Hz}$, 1H, ArH), $7.20 \sim 7.09(\mathrm{~m}, 7 \mathrm{H}, \operatorname{ArH}), 6.88(\mathrm{~d}, J=8.5 \mathrm{~Hz}$, $2 \mathrm{H}, \mathrm{ArH}), 6.69(\mathrm{~s}, 1 \mathrm{H}, \mathrm{NC}=\mathrm{CH}), 5.49\left(\mathrm{~s}, 2 \mathrm{H}, \mathrm{ArCH}_{2}\right), 3.74$ $\left(\mathrm{s}, 3 \mathrm{H}, \mathrm{ArOCH}_{3}\right), 3.64 \sim 3.38(\mathrm{~m}, 6 \mathrm{H}$, piperazine- $\mathrm{H}$, $\left.\mathrm{ArCH}_{2}\right), 2.39 \sim 1.93\left(\mathrm{~m}, 4 \mathrm{H}\right.$, piperazine-H); ${ }^{13} \mathrm{C}$ NMR (101 $\left.\mathrm{MHz}, \mathrm{DMSO}-d_{6}\right) \delta: 162.42,161.88\left(J_{\mathrm{C}-\mathrm{F}}=244.42 \mathrm{~Hz}\right)$, $158.84,137.50,135.02\left(J_{\mathrm{C}-\mathrm{F}}=3.03 \mathrm{~Hz}\right), 131.88,130.57$, $129.94,129.55\left(J_{\mathrm{C}-\mathrm{F}}=8.08 \mathrm{~Hz}\right), 126.52,123.67,121.88$, $120.71,115.83\left(J_{\mathrm{C}-\mathrm{F}}=22.22 \mathrm{~Hz}\right), 114.06,111.05,104.27$, 61.69, 55.46, 52.66, 46.45; HRMS calcd for $\mathrm{C}_{28} \mathrm{H}_{29} \mathrm{FN}_{3} \mathrm{O}_{3}$ $[\mathrm{M}+\mathrm{H}]^{+}$458.2244, found 458.2232.

(1-(4-Fluorobenzyl)-1H-indol-2-yl)(4-(4-fluorobenzyl)piperazin-1-yl)methanone (7l): White solid, yield $42.9 \%$. m.p. $98.8 \sim 101.4{ }^{\circ} \mathrm{C}$; $1 \mathrm{H}$ NMR (400 MHz, DMSO- $\left.d_{6}\right) \delta$ : $7.66 \sim 7.59(\mathrm{~m}, 2 \mathrm{H}, \mathrm{ArH}), 7.34 \sim 7.28(\mathrm{~m}, 2 \mathrm{H}, \mathrm{ArH}), 7.23(\mathrm{t}$, $J=7.7 \mathrm{~Hz}, 1 \mathrm{H}, \mathrm{ArH}), 7.18 \sim 7.08(\mathrm{~m}, 7 \mathrm{H}, \mathrm{ArH}), 6.70(\mathrm{~s}$, $1 \mathrm{H}, \mathrm{NC}=\mathrm{CH}), 5.49\left(\mathrm{~s}, 2 \mathrm{H}, \mathrm{ArCH}_{2}\right), 3.63 \sim 3.45(\mathrm{~m}, 4 \mathrm{H}$, piperazine-H), $3.40\left(\mathrm{~s}, 2 \mathrm{H}, \mathrm{ArCH}_{2}\right), 2.40 \sim 1.94(\mathrm{~m}, 4 \mathrm{H}$, piperazine-H); ${ }^{13} \mathrm{C}$ NMR (101 MHz, DMSO- $\left.d_{6}\right) \delta: 162.42$, $161.88\left(J_{\mathrm{C}-\mathrm{F}}=243.41 \mathrm{~Hz}\right), 161.80\left(J_{\mathrm{C}-\mathrm{F}}=244.42 \mathrm{~Hz}\right)$, 137.50, $135.02\left(J_{\mathrm{C}-\mathrm{F}}=3.03 \mathrm{~Hz}\right), 134.33\left(J_{\mathrm{C}-\mathrm{F}}=3.03 \mathrm{~Hz}\right)$, $131.85,131.16\left(J_{\mathrm{C}-\mathrm{F}}=8.08 \mathrm{~Hz}\right), 129.54\left(J_{\mathrm{C}-\mathrm{F}}=8.08 \mathrm{~Hz}\right)$, $126.51,123.68,121.88,120.71,115.83\left(J_{\mathrm{C}-\mathrm{F}}=21.21 \mathrm{~Hz}\right)$, $115.42\left(J_{\mathrm{C}-\mathrm{F}}=21.21 \mathrm{~Hz}\right), 111.06,104.30,61.32,52.67$, 46.46; HRMS calcd for $\mathrm{C}_{27} \mathrm{H}_{26} \mathrm{~F}_{2} \mathrm{~N}_{3} \mathrm{O}[\mathrm{M}+\mathrm{H}]^{+}$446.2044, found 446.2036 .

(1-(4-Fluorobenzyl)-5-(methylsulfonyl)- $1 H$-indol-2-yl)(4-(4-methoxybenzyl)piperazin-1-yl)methanone (7m): White solid, yield $40.2 \%$. m.p. $65.5 \sim 67.8{ }^{\circ} \mathrm{C}$; ${ }^{1} \mathrm{H}$ NMR $\left(400 \mathrm{MHz}, \mathrm{DMSO}-d_{6}\right) \delta: 8.25$ (s, $\left.1 \mathrm{H}, \mathrm{ArH}\right), 7.92(\mathrm{~d}, J=8.8$ $\mathrm{Hz}, 1 \mathrm{H}, \mathrm{ArH}), 7.76$ (d, $J=8.8 \mathrm{~Hz}, 1 \mathrm{H}, \mathrm{ArH}), 7.20 \sim 7.12$ $(\mathrm{m}, 6 \mathrm{H}, \mathrm{ArH}), 6.95(\mathrm{~s}, 1 \mathrm{H}, \mathrm{NC}=\mathrm{CH}), 6.88(\mathrm{~d}, J=8.4 \mathrm{~Hz}$, $2 \mathrm{H}, \mathrm{ArH}), 5.57\left(\mathrm{~s}, 2 \mathrm{H}, \mathrm{ArCH}_{2}\right), 3.74\left(\mathrm{~s}, 3 \mathrm{H}, \mathrm{ArOCH}_{3}\right)$, $3.67 \sim 3.37\left(\mathrm{~m}, 6 \mathrm{H}\right.$, piperazine- $\left.\mathrm{H}, \mathrm{ArCH}_{2}\right), 3.20(\mathrm{~s}, 3 \mathrm{H}$, $\left.\mathrm{SO}_{2} \mathrm{CH}_{3}\right), 3.40 \sim 1.90\left(\mathrm{~m}, 4 \mathrm{H}\right.$, piperazine-H); ${ }^{13} \mathrm{C} \mathrm{NMR}$ $\left(101 \mathrm{MHz}, \mathrm{DMSO}-d_{6}\right) \delta$ : $162.01\left(J_{\mathrm{C}-\mathrm{F}}=244.42 \mathrm{~Hz}\right)$, $161.65,158.85,139.33,134.47,134.33\left(J_{\mathrm{C}-\mathrm{F}}=3.03 \mathrm{~Hz}\right)$, $133.33,130.56,129.90,129.72\left(J_{\mathrm{C}-\mathrm{F}}=9.09 \mathrm{~Hz}\right), 125.96$, $122.34,121.66,116.01\left(J_{\mathrm{C}-\mathrm{F}}=21.21 \mathrm{~Hz}\right), 114.07,111.96$, 105.50, 61.64, 55.46, 52.54, 46.92, 44.75; HRMS calcd for $\mathrm{C}_{29} \mathrm{H}_{31} \mathrm{FN}_{3} \mathrm{O}_{4} \mathrm{~S}[\mathrm{M}+\mathrm{H}]^{+}$536.2019, found 536.1999.

\subsection{Biological activity}

\subsubsection{Methyl thiazolyl tetrazolium assay}

The antiproliferative activity of compounds against A549, HCT-116, and SGC-7901 (ATCC, Rockville, MD, USA) cell lines was evaluated by methyl thiazolyl tetrazolium assay (MTT) assay. Exponentially growing cells were harvested and plated in 96-well plates at a concentration of $1 \times 10^{5}$ cells/well. The cells in wells were treated with title compounds, respectively, at various concentrations for $72 \mathrm{~h}$. Then, $20 \mu \mathrm{L}$ of MTT $(5 \mathrm{mg} / \mathrm{mL})$ was added to each well and incubated for $4 \mathrm{~h}$ at $37^{\circ} \mathrm{C}$. Supernatant was discarded, and $150 \mu \mathrm{L}$ of dimethyl sulfoxide (DMSO) was added to each well. Absorbance values were determined at $570 \mathrm{~nm}$. The $\mathrm{IC}_{50}$ values were calculated by Graphpad 5.0.

$$
\text { Inhibition rate }(\%)=\frac{\mathrm{OD}_{\text {control }}-\mathrm{OD}_{\text {administration }}}{\mathrm{OD}_{\text {control }}} \times 100 \%
$$

\subsubsection{In vitro $\mathrm{COX}$ and 5-LOX inhibition assay}

The inhibitory COX activity of the tested compounds and the reference was assayed using COX-1 Inhibitor Screening Kit (Fluo-rometric) (BioVision, Inc., Mountain View, CA, USA) and COX-2 Inhibitor Screening Kit (Beyotime Biotech Co., Ltd, China) according to the manufacturer's instructions. COX-1/COX-2 Assay Buffer (398 mL), COX-1 Cofactor $(2 \mathrm{~mL})$ and arachidonic acid solution were placed in a 96-well plate. The test compounds were added to above solution. The plate incubated for $5 \mathrm{~min}$ at $37{ }^{\circ} \mathrm{C}$ and fluorescence was measured. The excitation wavelength was 535 $(\mathrm{COX}-1)$ and $560(\mathrm{COX}-2) \mathrm{nm}$, and the emission wavelength was 587 (COX-1) and 590 (COX-2) nm.

The recording groups were divided into RFU (Relative Fluores-cence Unit) blank control, RFU 100\% enzyme activity control, RFU positive drug control, and RFU test compound. Calculation of the inhibition rate was carried out according to the following equations. The $\mathrm{IC}_{50}$ values were calculated from the concentration curves.

$$
\text { Inhibition rate }(\%)=\frac{\mathrm{RFU}_{\text {enzyme }}-\mathrm{RFU}_{\text {compound }}}{\mathrm{RFU} U_{\text {enzyme }}-\mathrm{RFU} U_{\text {blank }}} \times 100 \%
$$

$\mathrm{RFU}_{\text {enzyme }}$ is RFU $100 \%$ enzyme activity control; $\mathrm{RFU}_{\text {blank }}$ is RFU blank control; $\mathrm{RFU}_{\text {positive }}$ is RFU positive drug control.

A 96-well microplate was provided with a background well, a control well, a sample well and a sample background well, respectively. Buffer, DMSO, HRP (Sigma-Aldrich, St. Louis, MO), 5-LOX (Sigma-Aldrich, St. Louis, MO) 
and the test drug were added to the wells, and the wells were incubated at $37{ }^{\circ} \mathrm{C}$ for $10 \mathrm{~min} .10 \mu \mathrm{L}$ of chromogenic substrate TMB (Sigma-Aldrich, St. Louis, MO) and AA (Sigma-Aldrich, St. Louis, MO) were added to each well to activate the reaction. Then, the microplate was carefully shaken to mix the solution, and was incubated at $37{ }^{\circ} \mathrm{C}$ for $15 \mathrm{~min} . \mathrm{H}_{2} \mathrm{SO}_{4}(1 \mathrm{~mol} / \mathrm{L})$ terminator was added, and the absorbance at $450 \mathrm{~nm}$ was measured with a microplate reader.

Calculation of the inhibition rate was carried out according to the following equations. The $\mathrm{IC}_{50}$ values were calculated from the concentration curves.

$$
\text { Inhibition rate }(\%)=\frac{O D_{\text {enzyme }}-\mathrm{OD}_{\text {compound }}}{\mathrm{OD}_{\text {enzyme }}-\mathrm{OD}_{\text {blank }}} \times 100 \%
$$

$\mathrm{OD}_{\text {enzyme }}$ is OD $100 \%$ enzyme activity control; OD $\mathrm{OD}_{\text {blank }}$ is OD blank control; $\mathrm{OD}_{\text {positive }}$ is OD positive drug control.

\subsubsection{Cell apoptosis assay}

Exponentially growing A549 cells were harvested and plated in 6-well plates at a concentration of $5 \times 10^{5}$ cells/well. The cells in wells were treated with different concentrations of compound $7 \mathbf{b}(0,3.125,6.25,12.5,25$ $\mu \mathrm{mol} \cdot \mathrm{L}^{-1}$ ) for $48 \mathrm{~h}$ after being incubated overnight. The cells were collected and washed with cold PBS $\left(4{ }^{\circ} \mathrm{C}\right)$ and centrifuged at $1000 \mathrm{r} / \mathrm{min}$ for $5 \mathrm{~min}$ at $4{ }^{\circ} \mathrm{C}$. The supernatant of each well was discarded. Then $1 \times$ Annexin $\mathrm{V}$ binding solution was added for resuspension, and Alexa Fluor 488 annexin $\mathrm{V}$ and PI $(100 \mu \mathrm{g} / \mathrm{mL})$ working solution were added. After incubating the cells at room temperature for 15 min, they were analyzed by flow cytometry.

\subsection{Docking studies}

The molecular docking simulation was performed using the AutoDockTools-1.5.6 module in ANTODOCK 4.2.6. Referred to the reported co-crystal structure of COX-2 protein (PDB code: 1CX2) and endogenous ligand (SC-558) to determine its active pocket. Ligands and water molecules were removed from proteins. Active pockets were automatically generated based on endogenous ligands, and the treated ligands were docked to the active pockets of
COX-2. After the docking was completed, according to the scoring results, the best conformation of the ligand with better energy complement and spatial complement with the docking protein was selected. The interaction of the ligand with the key amino acid residues of the docking protein at the active site was observed, and the type of interaction was analyzed.

Supporting Information ${ }^{1} \mathrm{H}$ NMR and ${ }^{13} \mathrm{C}$ NMR spectrum of compounds $\mathbf{7 a} \sim \mathbf{7 m}$. The Supporting Information is available free of charge via the Internet at http://siocjournal.cn.

\section{References}

[1] Whiteman, D. C.; Wilson, L. F. Cancer Epidemiol. 2016, 44, 203

[2] Qu, X. L.; Tang, Ying.; Hua, S. C. Front. Immunol. 2018, 9, 563.

[3] Riemann, A; Ihling, A.; Reime, S. Adv. Exp. Med. Biol. 2016, 923, 105.

[4] Zhang, L.; Wang, Z. C.; Li, X. E. J. Med. Chem. 2019, 169, 168.

[5] Marsico, F.; Paolillo, S.; Filardi, P. P. J. Cardiovasc. Med. 2017, 18, 40.

[6] Jacqueline, K. L.; Philip, C. C. Prostaglandins, Leukotrienes Essent. Fatty Acids 2018, 132, 41.

[7] Jacob, P. J.; Manju, S. L.; Ethiraj, K. R. Eur. J. Pharm. Sci. 2018, $121,356$.

[8] Nicholas, S. K.; Joan, R.; Blerina, A. S. Cardiovasc. Res. 2019, 12, 12.

[9] Soumaoro, L. T.; Iida, S.; Uetake, H. World J. Gastroenterol. 2006, 12,6355 .

[10] Cai, H.; Huang, X. J.; Xu, S. T. E. J. Med. Chem. 2016, 108, 89.

[11] Reddy, K. K.; Vidya, R. V. K.; Gupta, A. BMC Res. Notes 2015, 8, $1-10$.

[12] Guo, Z.-R. Acta Pharm. Sin. 2005, 11.

[13] Huang, Y. Z.; Zhang, B.; Li, J. M. E. J. Med. Chem. 2019, 180, 41.

[14] Alford, J. S.; Davies, H. M. L. J. Am. Chem. Soc. 2014, 136, 10266.

[15] Huang, W. J.; Wang, Y. J.; Li, J. M. Chem. Biol. Drug Des. 2018, 93, 110 .

[16] Bowers, A. A.; West, N.; Newkirk, T. L. Org. Lett. 2009, 11, 1301

[17] Kurumbail, R. G.; Stevens, A. M.; Gierse, J. K. Nature 1996, 384, 644.

[18] Scott, W. R.; James, R. K.; Jeffery, J. P. J. Biol. Chem. 2003, 278, 45763. 